\title{
The Pattern Settlement of Adat Delict of Waropen Tribe
}

\author{
Daniel Tanati \\ Senior Lecturer at Faculty of Law, University of Cenderawasih, Papua
}

\begin{abstract}
The Adat delict of Waropen Tribe can be settled in some approaches such as the normative law, the social sciences, sociology, and anthropology of law. Some theories wrote by some experts such as Franz von BendaBecmann and Sally Falk Moore are applied to draw how those approaches are working together in settling Adat Delict in Waropen Tribe. The pattern settlement of the Adat Delict can be settled into the Governor's Court, the Adat's Court or the Native's Court, the Swapraja's Court, the Village's Court, and/or Judicial Independence period. Related to Waropen tribes, not all of Waropen peoples are aware of customary or village courts. It is because the Waropen peoples only recognize the existence of a dispute resolution mechanism according to local customary law. The basic regulation of the Customary (Adat) court can be seen in some Laws such as the Law No. 1 Drt of 1951 (the Emergency Law) concerning Provisional Measures to Organize the Composition, Power and Procedure of Courts, Civil Courts, the Law No. 19 of 1964 concerning the Principal Provisions of Judicial Power, The Law No. 22 of 1999 concerning Regional Government, the Law No. 21 of 2001 concerning Special Autonomy for the Province of Papua and some the Regulation Government.
\end{abstract}

Keywords: the Settlement Patterns, the Adat Delict, Waropen Tribe

DOI: $10.7176 / \mathrm{JLPG} / 89-03$

Publication date:September $30^{\text {th }} 2019$

\section{Introduction}

Long before various legal traditions entered the archipelago, the people who lived in the archipelago were believed to have had a rule of law derived from the values of "chthonic" law. The term "chthonic" comes from the Greek term khthon or khthononos ${ }^{l}$ which means earth. The term "chthonic" law will be used to refer to the tradition of customary law which is believed to have lived since the beginning of the formation of indigenous people in the archipelago. The use of the term "chthonic law" to refer to the indigenous customary law of the Indonesian people is attributed (the ratio: family relations, family ties) to the use of the term "chthonic" itself as described by Edward Goldsmith when describing the culture of people's lives in harmony with the earth. ${ }^{2}$ The description of the legal tradition chthonic Indonesia will be focused on the legal traditions - as known so far as the customary law, which is believed to be a legal system that has a special character and are found only in the archipelago. ${ }^{3}$

In everyday expressions, the term custom (Adat) is often translated as a habit (custom) or customary law or commonly known as a legal tradition. However, in its development, the term Adat itself is not simple in its original meaning taken from the Arabic 'adah or ' urf ${ }^{4}$ The complexity of the term customary basically be divided into - in three aspects: ${ }^{5}$ First, the term Adat can have meaning as laws, rules, teachings, morality, habits, agreements, or actions that are in accordance with the habits of the community. In many ways, a very definite meaning depending on the context, but generally have the same meaning, namely behaviour holds true in people's lives in line with other people and the nature itself. Second, the term Adat is sometimes used in conjunction with customary practices that apply in a particular area, which covers a wide area ranging from Southern Thailand to the Southern Philippines, through the islands of Malaysia and Indonesia. Indeed, each place has its own customs depending on the cultural identity and language. Third, the term Adat is a large collection of literature from and about Adat produced by experts, administrators and legal experts. Although the development of Adat is currently in a passive state, the discussion about Adat actually never stops and continues to grow in line with the progress of knowledge about Adat itself. This is because Adat is not only discussed and written by experts from the socio-anthropological side, but also from its normative aspects.

In its development, disputes in the context of Adat often arise in the indigenous community itself. The resolution of Adat disputes is very urgent to be carried out in view of the enormous potential for conflict. In the Waropen tribe, the resolution of Adat disputes plays an important role in creating patterns of harmony within the indigenous community itself. Therefore, the focus of this paper is how the pattern of settlement of Adat delict in

\footnotetext{
${ }^{1}$ The terminology of khthon or khthononos means original or first known to exist in a region/country. Chthonia or chthonic means to live or exist in the earth. See C.T. Onois (ed.), 1975, The Shorter Oxford English Dictionary, vol. 1, third edition, Clarendon Press, Oxford, p. 334.

${ }^{2}$ Goldsmith writes that "significantly, chthonic man has always recognized a hierarchical set of laws governing at once his own behaviour, that of his society, of the natural world and of the all-encompassing cosmos itself, laws which it is his moral duty to observe as rigorously as possible". Edward Goldsmith, 1998, The Way: An Ecological World-View, the University of Georgia Press, Athens, GA, p. 14.

${ }^{3}$ Ratno Lukito, 2013, Indonesia Law Tradition, IMR Press, Yogyakarta, p. 2.

${ }^{4}$ Adat in English known as custom and in French. As coutume.

${ }^{5}$ MB Hooker, 1978, Adat Law In Modern Indonesia, Oxford University Press, Kuala Lumpur, pp. 50-51.
} 
Waropen tribe.

\section{Theoretical Basis}

Several approaches in the social sciences, sociology, and anthropology of law can be used in explaining the problem of resolving the Adat delict (customary offenses) of the Waropen tribe. However, the approach of the legal normative is able to work togtether with those approaches. In terms of it, the theory of normative law of Roscoe Pound states that the law could be used as a tool of social engineering. It can be used to explain the relationship between the social sciences, sociology, and legal anthropology. This theory arises based on the assumption that social relations between individuals or groups that occur in society are very sensitive to the coming of human control. Of course human beings in this terms refers to people who use formal legal instruments as tools to control.

The normative law approach is different from the sociological approach. For example the theory from Cochrane. The theory states that the community is the party who controls social relations in question. It means that basically the community itself is actively finding, choosing and determining its own law. This view becomes important when family, land, environmental, and natural resource disputes are resolved through a sociologicalinductive approach.

In addition to the concepts and approaches as mentioned above, anthropological concepts are deemed necessary to be proposed as a solution to the approach to resolving conflicts. In this context, dispute process is divided into 4 (four) stages, namely potential conflict, pre-conflict, conflict, and dispute. The potential for conflict appears when in a society there are groups whose show its presence. Pre-conflict as the next stage would appear if one of the parties referred to in the practice group social relationships feel disadvantaged by the other groups.

The concept of conflict is a condition that indicates that a person or group of people feel is unfair. The unfair feeling is used as a background for the appearance of anger or immersion to complain. The unaddressed complaints by other parties are called the monadic conflict and if the complaint has been responded to by another party, it called the dyadic conflict stage. If an increase in conflict becomes public knowledge of third party either an individual or a group, the stage of the dispute becomes triadic. At this stage, the third party is involved because of an initiative by one or both of the main parties or supporters or at the request of the third party itself. ${ }^{1}$

Dispute resolution is a situation where the institution or parties to the dispute stop the dispute or the dispute is on hold. It is deemed resolved if the dispute resolution agency is able to stop the dispute and the effectiveness of a decision is determined. In the sense, the parties involved do not proceed to a higher level. The normative approach used is based on the concept of law described by Franz von Benda-Becmann states that law is a concept that includes complex rules consisting of normative or cognitive conceptions, the basis of actions, rules, and principles the basis of every society. Therefore, the actions of individuals or groups involved in a dispute become important if in the writing of the problem solving for the Adat delict of the Waropen tribe applies to a case study model. It means that it is used to study a case of conflict or dispute that occurs significantly in the community and is resolved in outside the court forum.

Subsequent relevant theory, then, is the theory of semi-autonomous social field of Sally Falk Moore. This theory basically says that in social units there are rules and customs which are usually used to resolve and regulate social relations between members in the social unit even though nationally there are rules governing the same thing. The settlement of disputes or disputes can be solved in some ways - namely negotiation, mediation, and arbitration. Negotiation is a process of resolving disputes that emphasizes a verbal communication that the parties involved in a dispute resolve themselves without the involvement of a third party as an intermediary. Arbitration itself is the process of resolving disputes which emphasizes the communication of parties involved in a dispute in the presence of a third party authorized to make decisions. Meanwhile, mediation is the process of resolving disputes which emphasizes a verbal communication between the parties involved with the involvement of a third party, but it is neutral and has no authority to decide other than to facilitate the dispute resolution process based on local potential. This mediation is usually activated after the settlement by negotiating a deadlock. Thus, the actual resolution of disputes based on local potential requires the presence of a third party as a mediator.

The forms of traditional sanctions in its development has undergo some changes which have followed the feelings of justice in the joint community. In addition, these sanctions must have been abandoned because they are no longer in line with universally recognized values in social life. Villages in the district Waropen largely indicate types of sanctions as fine. However, in the process of settlement of peace, there is indigenous rituals to be conducted by the Adat community and the rituals are very believed to neutralize public nuisance. The process of resolving the fulfilment of Adat obligations refers to the settlement process carried out by the customary law

\footnotetext{
${ }^{1}$ Neder and Todd, 1978, The Disputing Process, Colombia Press, New York, p. 15.
} 
community in which the customary law applies.

\subsection{The Governor's Court (Gouvernement Rechtspraak).}

The governor's court consists of 2 parts, namely civil court and military court. The civil court consists of 4 rooms (camera), namely:

1. Landgerecht (for all groups);

2. Inlandsche Rechtspraak (indigenous justice). For Java and Madura, the lower judiciary is districtsgereeht and regentschapsgerecht. The second level of the judiciary is the landraad judiciary. Whereas for the other regions (outside Java and Madura), the lower judiciary is negorijrechtbank, distrietsgerecht / districtsraad and magistraatsgerecht. All regions including Java and Madura, the upper judiciary and all these judiciaries are the landraad judiciaries.

3. Europeesche Rechtspraak (European judiciary). In principle, it applies to Europeans. The form of its judiciary is first level of judiciary - called residentiegerecht, the appeal level is Raad van Justitie, and the cassation level is Hoogerechtshof van Nederlandsch Indie.

4. Religious Courts, which specifically hearing cases for those who are Muslim. These types of judicary include those in Java and Madura, known as Priesteraad and Hof voor Islandsche Zaken; in Afdelingen Banjarmasin and Hoeloe Soengai, known as Kadi and in other areas such as Palembang, Jambi, Pontianak, Ternate, Ambon, Makassar and Bontain known as Opperkadi. ${ }^{1}$

Military judiciary consists of Krijgsraad, Zeekrijraad and Gerechtshof Military Hoog. Krijgsraad has the authority to prosecute Dutch soldiers with the rank of captain. These trials are in Cimahi, Padang and Makassar. Zeekrijgsraad, in principle the same as Krijgsraad, but in terms of the implementation, it is carried out on a warship. Military Hoog Gerechtshof is the highest military court body and is domiciled in Batavia. The authority of the military judiciary is to examine the appellate level of the Krijgsraad and Zeekerijgraad decisions. It is also a judicial body in the first and highest level of the Dutch army with the rank of officer. ${ }^{2}$

\subsection{Adat court or Native Court (Inheemsche Rechtspraak)}

According to Article 130 of the Indische Staatsregeling, as long as the Indonesian people are not allowed to have their own judiciary, judicial proceedings are carried out on behalf of the king in Indonesia. It means that there is recognition to both the courts conducted by the state and genuine courts. ${ }^{3}$ Initially, the Adat judiciary was only available in direct (administrative) areas. For the other regions (outside Java and Madura), it is planned that the court will be deleted and then integrated into the governor's court. However, the change in attitude of the Dutch government in 1928 has resulted in Staatblad 1932 No. 80, which regulates the composition, position, power of adjudicating, material law and procedural law of customary judicial bodies, in which Article 1 stipulates that for regions across the form of judiciary is still recognized its existence. Staatblad 1932 No. 80 gives a very large authority to the Resident because this official is not only authorized to appoint judges, but also has the authority to set limits on the authority to judge for each of the judges and the judiciary mentioned above. ${ }^{4}$ Article 3 of the Staatblad further determines that the power to adjudicate from customary judiciary is exercised by:

1. Regional judges of legal units;

2. Religious judges; and

3. others court assemblies and judges. ${ }^{5}$

In general, customary judiciary consist of 3 levels of courts, namely:

1. Village court level (Meeting);

2. Low court level (kleine meeting); and

3. High court (meeting groote)

The Village Court (meeting) and the Lower Court (meeting kleine) in principle have the same position. The Village Courts may only adjudicate small matters that are carried out by members of the local Adat association. Meanwhile, the meeting kleine tries small matters carried out by native people who are not local residents. The High Court (Goote Meeting) is a court of appeals for both types of judicial bodies or becomes a court of first instance if there is no the Village Court or the Lower Court in the village concerned. The Village Court decisions is the resident's power to cancel and order re-examination by the appointed judge.

Based on Staatblad 1932 No. 80, customary judicial jurisdictions are regulated as follows:

1. The Adat court has the authority to adjudicate cases that occur within the territory of a customary judicial body;

\footnotetext{
${ }^{1}$ Soetoprawiro Koemiatmanto, 1994, Government and Indonesian Judiciary, Its Origin and Development, Citra Adtiya Bakti, Bandung, pp. 113-114.

${ }^{2}$ Ibid. pp. 124-128

${ }^{3}$ Tresna, 1978, Indonesian Judiciary From Century to Century, Pradnya Paramita, Jakarta, p. 73.

${ }^{4}$ Ibid. p.75.

${ }^{5}$ Ibid.
} 
2. All indigenous people from whatever origin they may be accused or accused; and

3. All classes of population can be plaintiffs.

The Adat court includes in the region:

1. Onderafdeeling Padanglawas, afdeelingen Batakianden and Nias except Batoe-Eilanden (Residentie Tapanuli);

2. Onderafdeeling Mentawai-Eilanden and Kerinci District (Residentie Sumatra's Westkust);

3. Residentie Bengkoelen, except the capital city;

4. Palembang residents, except the capital city;

5. The former Sultanate of Riau-Lingga (residentie Riow en onderhoogrigheden);

6. Onderafdeelingen Boven-Mahakam and Pasir (residentie zuider en ooster afdeeling van Borneo);

7. The former Gorontalo kingdom (Manado residentie);

8. Adatgemeenschappen Gantarang-Adatinggi, Kidnang, Laikang, Wanora Waroe (residents of Celebes en onderhoorigheden);

9. Taoen, Nila en Seroea-Eilanden: Laboeha, Obi, Kekik en Lawineilanden (residentie Moluken);

10. Afoteeling Groot-Aceh and onderafdeeling Singkep (residentie Atjeh en onderhoorigheden);

11. Onderafdeelingen Boven-Kapoeas, Seinitoe and Pinohianden districts and Meliaoe (residentie westerafdeeling van Borneo); and

12. Afdeeling Lombok (residentie Bali en Lombok). ${ }^{1}$

\subsection{Swapraja's Court}

There are two forms of Swapraja's Court, namely the Swapraja's Court across the region and the Swapraja's Court in the vorstenlanden area. The Swapraja's Court is held on behalf of the Head of Swapraja. The existence of The Swapraja's Court was recognized by the Dutch East Indies government with Zelfbestuursregele 1938.

\subsubsection{Regional Self-Defense Judiciary}

The Swapraja's Court across the regions are regulated in the treaties of the kings in the Swapraja with the Dutch East Indies government, called "Korte Verklaring". ${ }^{2}$ Most recently, the Dutch East Indies government has enacted regulations on self-governing regions with a Governor General (GG) decree dated September 14, 1938 No. 29 contained in S. 1938 No. 529 (explanation in Bijblad 14099) called "Zelfbetuursregelen 1938". This regulation replaced Zelfbestuursregelen 1927 and entered into force on January 1, 1939. Its contents are to determine the rights, authority, and obligations of the Dutch East Indies government with regions outside Java that have their own government, whose relationship with the Dutch East Indies government is regulated in "Korte Verklaring" or "other agreement".

As far as court authority is concerned, the judges and regions that have their own government are stipulated in Article 12 Zelfbestuursregelen 1938, as follows:

(1) insofar as there is no other stipulation in this regulation, the residents of the Swapraja areas are the court and those regions. If more than one Swapraja, a joint court will be held and residents from each Swapraja area will be joint court.

(2) Unless otherwise specified in or above based on this regulation, residents of the Swapraja area are tried by the Swapraja judge, both as defendants and plantiffs. The regional Swapraja judge also tried:

1. criminal charges against persons who are not residents of the Swapraja area in cases that are within their authority, if at the time of carrying out the act concerned they become citizens of the Swapraja area.

2. a lawsuit for civil cases against people who are not residents of the Swapraja area:

a. If the person is sued when he becomes a citizen of the area; and

b. concerning land, houses and plants which are controlled by Indonesian rights. ${ }^{3}$

Paragraph (3) contains a number of exceptions to the power to adjudicate Swapraja judges, which concern the dispute over the authority to adjudicate between Swapraja judges and other Indonesian judges. The dispute will be terminated according to the regulations stipulated by the Dutch Indies government.

It is the case the same to the Adat courts, the power of the resident is enormous because both the composition, the authority to judge, and the law of the event are determined by the resident with the assistance of the Swapraja government. In addition, the resident has the authority to determine (with the approval of the Swapraja government) which autonomous judges will be assisted by a civil servant appointed by the resident as an advisor. The considerable authority of the resident also appears from his role in supervising the decisions of the Swapraja court, even in certain cases the resident can also strengthen, change and cancel to the decision of the Swapraja court.

\subsubsection{The Swapraja Court in Vorstenlanden.}

Based on Rijksblad 1927 No. 35, the Swapraja courts in Java and Madura were found in the Ngayogyakarta

\footnotetext{
${ }^{1}$ Soetoprawiro Koemiatmanto, op.cit., pp. 114-117.

2 Tresna, p. 83

${ }^{3}$ Ibid. p.84.
} 
Hadiningrat Sultanate, whereas the Soerakarta Hadiningrat's residence was based on 1930 Rijksblad No. 6 and in the Mangkunegaran Duchy based on Rijksblad 1917 No. 22. The Swapraja court in the Sultanate of Ngayogyakarta covered:

1. The Surambi Court.

It is a religious court which was chaired by a chief judge (hoofpenghoeloe) as the sole judge. This court had the authority to try cases of marriage, divorce and reconciliation and heirs to the relatives of the sultan and "Rapak" (a request for divorce by all wives for all subjects. An appeal on the verdict of the surambi court could be appealed to the governor and then the sultan.

2. The Dalem Regional Palace Court.

It was an assembly court consisting of a chairman and two members and was assisted by a court clerk plus a prosecutor and a head. All these officials were appointed by the sultan. The head of the court was usually held by Prince Pati (the crown prince) or Prince Ngabehi (the eldest son of a concubine's wife) or a prince appointed by the sultan. The authority of this court was to examine and try criminal cases similar to criminal cases handled by Landsgerecht. For civil cases, this court was authorized to adjudicate all cases which were not handled by the court of empire or the sultan himself. Appeals regarding the court's decision could be requested by the sultan.

3. The Court by the Sultan.

This form of court is to try criminal cases where the perpetrator was the prince Pati and his family, as well as the wives of the sultan. As for civil cases, the sultan's authority was to adjudicate cases that did not belong to the Surambi court. This court was a court for the first and last instance for all types of cases mentioned above. ${ }^{1}$

The Swapraja court in Soerakarta Hadiningrat Sunanate included, among others:

1. The Pradata Court.

This type of court was conducted by a single judge and a court clerk. The authority of this judicial court was the same as Landsgerecht.

2. The Surambi Court.

This court was in essence a religious court conducted by a Wedana Yogaswara (Surakarta religious community official) as a single judge. The authority of this court was to hear cases relating to marriage, divorce, reconciliation and inheritance matters. Appeals to the Surambi court decisions could be appealed to a large the Pradata court.

3. The Pradata Gede Court.

This court examined the case with a panel of judges, the composition of which consisted of a chairman and two rights members. In addition, it was also equipped with a prosecutor and an official who were all appointed by the governor. This type of court was the highest court. The authority of this court in addition was to examine civil cases and criminal cases. ${ }^{2}$

The Swapraja Judiciary in the Duchy of Mangkoenegaran consists of:

1. The Surambi Court.

For this type of court, the principle is the Surambi court in the Yogyakarta Sultanate and the Surakarta court was not different. The Surambi Court in the Mangkunegaran Duchy was a religious court with an assembly system. Acting as the presiding judge was the chief judge who was assisted by several "Katib" as member judges. The authority of this court was to examine and decide cases relating to marriage, divorce, reconciliation and inheritance matters. Appeals for the Surambi court could be appealed to the Pradata court.

2. The Pradata Court.

This court was also a court with a system of assemblies. Acting as the chairman of the assembly was governor assisted by a number of members, plus a prosecutor and chief, but for summary criminal cases. This court would try with a single judge. This court had the authority to examine and try all civil and criminal cases that awee not under the court's authority. ${ }^{3}$

\subsection{The Village Court}

There are two types of village court, namely the village court which is part of the governing body of the governing court and the village court which stands alone. This independent court is recognized by the Dutch government through Rechtterlijk Orgarisatie (RO). In the relations of the Dutch East Indies government organization, the village was recognized as a legal entity based on Adat, although in the regulations on village households issued by the Dutch East Indies Governor and in 1906, namely the so-called "Inlandsche Gemeenteordonantie". It was not mentioned that at the village the court in village level is carried out according to local customs, but it does not mean that the village court did not exist. In 1935 the Dutch East Indies

\footnotetext{
${ }^{1}$ Soetoprawiro Koemiatmanto, op.cit., p. 118

${ }^{2}$ Ibid. pp.119-120.

${ }^{3}$ Ibid.pp. 121-122.
} 
government realized the importance of village judges who later officially recognized the village judges by inserting Article 3 (a) and (s) 1935 No. 102 into RO. ${ }^{1}$ Article 3 RO stipulates that cases which, according to adat law, come under the authority of village judges, those cases will still be tried by village judges, who will judge based on Adat law. However, the village judges are not allowed to impose sentences, so the village judge only acts as a peace judge. The decision of the village peace judge, at the most in the form of an apology, peace, restoration of balance, etc., is outlined in broad terms the judicial authority during the occupation of the Japanese army in Indonesia.

Immediately after the island of Java was occupied and fully controlled by the Japanese army, the Japanese army legislation was issued on March 8, 1942 No.1, which was determined in the law, that for the time being all the rules and regulations originating from and the Dutch government was declared still valid as long as it did not conflict with the regulations of the Japanese army. ${ }^{2}$ Initially the formation of justice by the Japanese army was more intended to protect military interests, so what was called Gunrikutaigi was formed. Its formation was based on Osamu Gunrei No. 2 Tabun 1942. Gunrikutaigi has the authority to examine and prosecute criminal cases that are qualified as crimes that are disturbing, counteracting and obstructing the Japanese army. Penalties can be imposed by Gunrikutaigi including imprisonment, banishment, fines and traditional penalties. In addition, Osamu Gunrei also justifies the imposition of cumulative crimes. ${ }^{3}$

In addition to the judiciary was formed for the sake of protecting the interests of the Japanese military with Osamu Gunrei No.2 in 1942 (which was later amended by Law No. 34 of 1942), a Gunsei Hoin (Governmental Army Court) was formed. These two laws became the basis for the formation of judicial organizations in Java and Madura. In principle, the organization and structure of the judiciary were the same as the organization and structure of the previous judiciary (during the Dutch East Indies) with the necessary changes. These changes have a very important meaning because: 1) the abolition of the difference between the governorate justice and the Bumi Putra court; 2) judges for the European group are abolished; 3) the judge for the Bumi Putra group has expanded their authority to include all groups; 4) the abolition of the authority to judge in the first instance from Raad van Justitie and Hooggerchtshof; 5) removal of the Residentiegerecht court; 6) changes in terms of the judiciary, such as Landraad to Tihoo Hooin (district court), Landgerecht to Keizai Hooin (police court), Regentschapsgerecht to Gun Hooin (court of justice), Hoof voor Islandsche Zaken to Kaikyoo Kootoo Hoin (High Islamic Court), Priesterraad becomes Sooryoo Hooin (religious meeting). For regions outside Java and Madura, it was only implemented two years after the enactment of Law No. 14 of 1942 with implementing regulations in the form of Timo Seirei Otsu No. 40 of 1943, which entered into force on 1 January $1944{ }^{4}$

\subsection{The Authority of Judicial Independence period}

The post-proclamation government policy to conduct unification in the field of law and also concerning the issue of judicial power is followed up with the ratification of the Law on Judicial Power, which since the proclamation of independence, up to now has been enacted in 4 (four) laws, namely:

1. Law No. 19 of 1948;

2. Law No. 19 of 1964 ;

3. Law No.14 of 1970 ;

4. Law No. 35 of 1999; and

5. Law No. 4 of 2004.

The promulgation of Law No. 14 of 1970 cannot be released with the determination of the new order to implement the 1945 Constitution in a pure and consistent manner, which was preceded by the legislative review, with the issuance of 4 legislative products, namely:

1. Law No.25 of 1968 concerning statements of non-validity of various Presidential Decrees and Presidential Regulations;

2. Law No.5 of 1969 concerning the statement of various Presidential Decrees and Presidential Regulations as Laws;

3. Law No.69 of 1969 concerning the statement of non-validity of the Law and Government Regulations in lieu of the Act; and

4. Law No.7 of 1969 concerning Stipulation of Various Government Regulations in Lieu of Laws into Laws.

The Law No. 6 of 1969 stated that the Law No. 19 of 1964 was invalid because the contents of the Law No. 6 of 1969 clearly contained contradictory material to the 1945 Constitution, but when it was not valid that it was determined when the Act that replaced it came into force. ${ }^{5}$ For this purpose the Law No. 14 of 1970, concerning

\footnotetext{
${ }^{1}$ Tresna, op.cit., p.72.

2 Ibid., p.85.

${ }^{3}$ Further see, Sudikno Mertokusumo, 1984, The History of Justice and Legislation in Indonesia Since 1942 and What Its Benefits Are for Us Indonesians, Liberty, Yogyakarta, pp. 11-13.

${ }^{4}$ Ibid. pp.14-20.

${ }^{5}$ Further see Z. Asikin Kusumah Atmadja, 1980, "Politics of National Law" in Abdul H. Nusantara and Nasroen Yasabari (ed.) Some
} 
the Principles of Judicial Power. The types of judicial power in the Law No. 14 of 1970 are determined in Article 10 which states that judicial power is exercised by:

1. General Courts.

2. Religious Courts.

3. Military Justice.

4. State Administrative Court.

The General Court can be further seen in the Law No.2 of 1986, which simultaneously revoked the Law No.13 of 1965 concerning Courts in the General Courts and the Supreme Court. In the Article 3 paragraph (1) of the Law No. 2 of 1986, it is determined that judicial power within the general court is carried out by the district court and the high court. Each of these judicial bodies is domiciled in the district or municipal capital and provincial capital (Article 4). The district court is the first court and the high court is the court of appeal (Article 6). The exclusion of the supreme court in the scope of the general court due to it is not only a court of appeal for the general court, but also for the religious, military and state administrative courts.

The Religious Court is a special judicial body for those who convert to Islam. The existence of this religious court is regulated in the Law No. 7 of 1989. Judicial power in rthe eligious courts is exercised by the religious courts and religious high courts Each of which is domiciled in the district or municipal capital and provincial capitals (Article 3 and Article 4). For the Military Court, its regulation is contained in the Law No. 31 of 1997. The Military Court is a special court, which has the authority to try military criminal cases and military administration. Legal subjects that can be tried in military criminal cases include:

1. Soldier;

2. They are equated with soldiers under the legislation;

3. A Members of a group or department or agency or equivalent or be considered as a soldier under the legislation;

4. For those who do not include the letters $\mathrm{a}, \mathrm{b}$ and $\mathrm{c}$, but by decision of the commander with the approval of the justice minister should be tried by a court in the military courts.

In addition to this, Article 9 paragraph (3) of the Law No.31 of 1997 stipulates that the military court has the authority to combine compensation claims in a criminal case upon the request of the injured party, which at the same time decides it in a single decision. Judicial power in the military court environment, among others carried out by:

1. Military Court.

2. Military Court of Appeal.

3. Main Military Court.

4. Battle Military Court.

The Military Court is a court of first instance for soldiers with the rank of captain, whereas the Military High Court is an appellate court for the Military Court and is also a court that examines in the first instance for soldiers with the rank of major and above. The main Military Court is an appellate court of the Military High Court which has decided in the first instance of a military criminal case and the administrative case of the armed forces (Article 40, Article 41 and Article 42 of Law No. 31 of 1997). Each of these court bodies for the Military Court and the Military High Court, their place of residence is regulated by Decree of the Commander in Chief, while for the main military court is located in the national capital (Article 14). For the Military Court forms of battle, the position is not fixed, but follows the movements of troops who are carrying out operational tasks (fighting). The military court battle authorizes to examine and decide on military criminal cases in the first and last instance. The defendants are soldiers involved in operational tasks (fighting) according to Article 45 and Article 46 of the Law No. 31 of 1997.

The State Administrative Court (PTUN) is regulated by the Law No.5 of 1986. This court is a special court (Article 4) because it is one of the executors of the power of the judiciary for the people seeking justice for state administrative disputes. The exercise of judicial power within the scope of the state administrative court includes, among others:

1. Administrative Court.

2. State Administrative High Court.

The State Administrative Court is the first court, while the High State Administrative Court is the court of appeal. In the cassation level is the Supreme Court (Article 5, Article 6 and Article 8 of Law No. 5 of 1986).

As I have stated, that during the Dutch administration, the village court was regulated in Article 3 (a) RO. In this article, it was determined:

1. cases which according to customary law include the authority of judges and small jurisdictions (village judges) continue to be tried by these judges.

2. the provisions of the foregoing paragraph do not reduce the right of litigants to submit their cases to governor 
judges and Swapraja judges.

3. village judges in adjudicating cases according to their customary law must not sentence.

RO is valid until the Law No. 1 of 1950 LN. 1950 No. 3 concerning the Composition and Power of the Supreme Court. RO is still questioned because on the one hand according to Chapter V, RO has been abolished by the enactment of the Law of the Supreme Court, but on the other hand, it still applies, especially for those articles are not regulated by the Supreme Court Law, such as Articles 180 and 181. This article regulates the power of the Attorney General as the chief of judicial police and preventive police chiefs. Even more basic is the existence of the village peace judge himself. Unlike the case with the Gubernemen and Swapraja courts (which in Bali are known as the "Kerta court or Raad Kerta"), with the enactment of the Law No. 1 of 1951, it has been declared to be abolished. The abolition of the Kerta trial in Bali was carried out by the Decree of the Minister of Justice No. 4/8/16, 9 March 1952 which was declared effective since 26 March 1952.

After the issuance of the Law No. 1 Drt of 1951 concerning Measures to Organize the Power and Civil Courts Unit, RO is still referred to as the legal basis for village peace judges (Article 3 a RO). Sudikno Mertokusumo stated that in the Law No. 1 Drt of 1951 contained 4 things, namely:

1. the elimination of some judiciary which is no longer suitable with the atmosphere of the unitary state;

2. the gradual abolition of autonomous the Swapraja court in certain areas and all traditional court;

3. continuation of the religious court and village court; and

4. the establishment of district courts and prosecutors in places, where the Langerecht or state courts were abolished and the establishment of the Makassar High Court and the relocation of the positions of the Yogya and Bukit Tinggi courts to Surabaya and Medan respectively. ${ }^{1}$

According to Article 3 paragraph (3) of the Law No. 1 Drt of 1951, the abolition of the aforementioned courts in paragraph (1) of this Law does not at all reduce the rights and powers so far granted to the village peace judge as referred to in Article 3 a RO, but in the explanation of the article it is found an explanation that in all regions of Indonesia all courts are state courts decide civil and criminal cases. "If the explanation of this article is related to the provisions in Article 1 paragraph (3), then it is clearly contradictory. Regarding this problem, Sudikno Mertokusumo states that "because the essence of a law or regulation is nothing but the sound of the articles and not the explanation, then we hold on to the sound of Article 1 paragraph (3) of the Law No. 1 Drt of 1951, so according to that article the village peace judge or village court (dorpsrechtters) as referred to in Article 3 a RO under the Government of the Republic of Indonesia Unity is maintained". 2

Sudikno furthermore states that "However, given that the village judge or village peace judge or what is often referred to as a village court is not a court in the real sense, then the village court cannot be considered as part of in the provisions of the Law No. 1 Drt of 1951 and can therefore be considered maintained". ${ }^{3}$ In the Article 10 paragraph (1) the Law No. 14 of 1970 states that, judicial power is exercised by the courts in the environment:

a) General Court;

b) Religious Courts;

c) Military Justice; and

d) State Administrative Court.

In the explanatory of the article, furthermore, it is obtained that this law distinguishes between four judicial environments, each of which has a certain jurisdiction of authority and includes judicial bodies of first instance and appellate court. Religious, military and state administrative courts are special courts because they try certain cases or concerning certain groups of people, whereas general court is a court of law for the people in general regarding both civil and criminal cases.

The differences in the four judicial environments do not rule out the possibility of specialization (differentiation/specialization) in each environment. For example in general court, specialties can be held in the form of traffic courts, juvenile courts, economic courts and so on with the law. Article 3 paragraph (1) determines that all courts in Indonesia are state courts and are determined by law. This article is intended to avoid the existence of other courts than the state court. If it is observed, there are possibility of settlement of cases through "peace way" such as arbitration. As it is known, the court is determined by law in order to prevent the formation of a court other than those intended by the Law No. 14 of 1970.

From the explanation above, it can be said that, although Article 10 paragraph (1) of the Law No. 14 of 1970 does not mention the existence of a village court, but according to Article 3 paragraph (1) of the Law no. 14 of 1970, the village court is still possible to be maintained. Likewise, the position of RO after the enactment of the Law on Criminal Procedure (KUHAP) does not cause problems because in this law is not mentioned about RO. It only determines that by the enactment of the Criminal Procedure Code the provisions governing criminal procedural law are declared to be revoked.

\footnotetext{
${ }^{1}$ Sudikno Mertokusumo, op.cit, p. 14

${ }^{2}$ Ibid., p.117.

${ }^{3}$ Ibid.
} 


\section{The Customary (Adat) Courts in Special Autonomy for Papua Province}

As has been explained above that in the colonial era there were two forms of judiciary for indigenous people namely "Customary Courts" and "Village Courts". Between the two judicial bodies, there is actually no principle difference. The Village Courts are generally found almost throughout the archipelago in indigenous territorial customary communities. However the Customary Court is found in communities that are territorial or genealogical. The two courts are related to the function of an adat law community (adatrechtgemeenschap) found in various indigenous peoples in the archipelago. Not all indigenous peoples are aware of customary or village courts because they only recognize the existence of a dispute resolution mechanism according to local customary law.

When the government enacted the Law No. 1 Drt of 1951 (the Emergency Law) concerning Provisional Measures to Organize the Composition, Power and Procedure of Courts, Civil Courts (LN. 1951 No. 9) on 13 January 1951. The government had firmly determined its attitude regarding the existence of Adat courts and the position of village courts. Basically the Emergency Law contained 4 things namely:

1. Elimination of several courts that no longer fit the atmosphere of the unitary state.

2. The gradual abolition of autonomous courts in certain regions and all Adat courts.

3. Continuation of religious and village courts; and

4. Establishment of district courts and prosecutors in places where Landgerecht or State Courts were abolished as well as the establishment of High Courts in Makassar and the relocation of the positions of the Yogya High Court and Bukit Tinggi Court respectively to Surabaya and Medan.

Article 1 paragraph (1) sub b of the Emergency Law states that at a time when it would be gradually determined by the Minister of Justice, all Customary Courts were abolished (Inheemse Rechtspraak in rechtsreeks bestuurd gebied), except for the Religious Courts if the court according to living law was a separate part of the Customary Courts. Then in paragraph (3) it is states that the provisions mentioned in paragraph (1) have not reduced the power that has so far been given to peace judges in the villages as referred to in Article 3a of the Organization.

The abolition of customary court is intended to create a unitary judicial system through a State Court. The abolition of Swapraja Court and Customary Court is not possible when the regulation is enacted. It is because the consequences for judges at the District Court are increased workload. In connection with this, the elimination of customary court is carried out gradually according to the need by taking into account the readiness of the judges in the district court.

To that end, the elimination of the Customary Court is carried out through several provisions such as:

1. The Minister of Justice Decree concerning the Elimination of Swapraja Courts and Customary Courts throughout Sulawesi, dated August 21, 1952 No. JB4 / 3/17 (TLN 276);

2. The Minister of Justice Decree concerning the Elimination of Customary Courts throughout Lombok, dated 30 September 1953 No. JB4 / 4/7 (TLN. 462);

3. The Minister of Justice Decree concerning the elimination of Swapraja and Adat courts in all Kalimantan Provinces, dated June 21, 1954 No. JB4 / 3/2 TLN. 461) jo. Decree of the Minister of Justice dated 18 August 1954 No. JBA / 4/20 (TLN. 642);

4. The Presidential Decree No. 6 of 1966 concerning the Elimination of Customary / Swapraja Courts and the Establishment of District Courts in West Irian Jaya. (This Presidential Decree with Law No. 5 of 1969 is stipulated into Act). As an implementation, a joint decree was issued by the Governor of West Irian Province and the Chairman of the Jayapura High Court No. 11 / GIB / 1970 / BO-11 / TV / 1970 concerning the Elimination of Customary / Swapraja Courts in the area of West Irian Province.

In the old order era, the Law No. 19 of 1964 concerning the Principal Provisions of Judicial Power (LN. 1964 No. 107). In this law, there is no explicit statement regarding the elimination of the Adat court. In it, there is only Article 1 paragraph (1) which states "all courts in the entire territory of the Republic of Indonesia are state courts determined by law". Explanatory of this article) concerning the Principal Provisions of Judicial Power (TLN. 14 of 1970 LN. 1970 No. 74. There are two Articles which specifically deal with the Adat court, namely:

1. Article 3 paragraph (1) states "all courts in the entire territory of the Republic of Indonesia are State Courts and are determined by law. The explanatory of this article (TLN. 2951) states that this article implies that in addition to state courts, there are no longer any trials conducted by non-state courts.

2. Article 39 mentions the Abolition of the Adat court and the Swapraja Courts conducted by the Government. Some of the explanations in this article state that based on the Law No. 1 Drt of 1951 concerning temporary measures to organize unity, power structure and civil court proceedings Article 1 paragraph (2) by the Minister of Justice has gradually been carried out with the removal of customary / Swapraja courts throughout Bali, the provinces of Sulawesi, Lombok, Sumbawa, Timor, Kalimantan, Jambi and Maluku.

The Law No. 22 of 1999 concerning Regional Government (LN. 1999 No. 60) began to reappoint the existence of village peace judges, although not explicitly. Article 101 states that there are two duties and 
obligations of the Village Head or the Village Representative Body namely: (1) maintaining the peace and order of the village community; and (2) reconciling community disputes in the village. Article 104 determines the Village Representative Body or what is referred to by other names, functions to protect customs, to make Village Regulations, to accommodate and channel the aspirations of the community, as well as to supervise the implementation of the Village Government. Then in Article 106, it is stated that in the Village other institutions can be formed in accordance with the needs of the Village and stipulated by a Village Regulation.

Regarding village institutions, Minister of Internal Affairs Decree No. 64 of 1999 concerning General Guidelines for Village Settings, which are used as guidelines by the district government in making a "Regional Regulation Package" on villages. Regarding the duties and obligations of the Village Head, Article 16 mentions the same contents as Article 101, among others, concerning the obligation to reconcile community disputes in the Village. It is only that there is an additional new task of preserving the customs that live and develop in the village concerned. This provision has placed the Village Head not only as the village leader, but also as an Adat functionary. Furthermore, in paragraph (3) and paragraph (4) this article regulates, as follows:

(3) To reconcile disputes as referred to in paragraph (1) letter o, the village head may be assisted by a village Adat institution;

(4) All disputes which have been reconciled by the village head are binding on the disputing parties.

The term Adat institution has previously been used in the Minister of Internal Affairs Instruction No. 17 of 1989 concerning the Development and Development of Customary Institutions in the Village / Kelurahan, dated May 30, 1989. This matter is then regulated further in the Minister of Internal Affairs Decree No. 3 of 1997 concerning Empowerment and Preservation and Development of Customs, and Customary Institutions in the Regions, dated February 14, 1997, which was then followed by the Minister of Internal Affairs Instruction No. 3 of 1997 concerning Empowerment and Preservation and Development of Customs, and Customary Institutions in the Regions.

In the Minister of Internal Affairs Decree No. 3 of 1997 on "Indigenous Institutions" was formulated as a social organization that was intentionally formed and naturally had grown and developed in the history of the community concerned or in a particular customary law community, and was entitled and authorized to regulate, manage and resolve various problems life related to and refers to applicable customs and customary law. \{Article 1 letter (o)\}. Then in Article 9 paragraph (1) of this regulation states that Adat institutions have the following rights and authorities to:

1. represent the community out, namely in matters relating to the interests and influences of adat;

2. manage customary rights and / or customary assets to improve the progress and standard of living of the people in a direction that is more feasible and better.

3. settle disputes concerning the cases of customs and habits of the community as long as the settlement does not conflict with applicable laws and regulations.

Based on this article, the "Adat Institution" is also an institution whose role is to resolve Adat disputes. So that this institution is suggested as a village court.

In the reform era, the Minister of Internal Affairs Decree No. 3 of 1997 and the Minister of Internal Affairs Instruction No. 15 of 1998 mentioned above was revoked by the Minister of Internal Affairs Decree No. 4 of 1999 concerning the Revocation of Several the Minister of Internal Affairs Regulation, the Minister of Internal Affairs Decree and the Minister of Internal Affairs Instruction regarding the implementation of Law No. 5 of 1979 concerning Village Government. Then with the regulation of customary institutions in the the Minister of Internal Affairs Decree No. 64 of 1999 can be considered as a continuation of traditional institutions that have been regulated in the Minister of Internal Affairs Regulation No. 3 of 1997. Article 43 of the Minister of Internal Affairs Decree No. 64 of 1999 states that the Regency Government can stipulate various policies in the effort to empower, preserve and develop customs and traditional institutions in the region. Then Article 44 states:

(1) Further arrangements regarding empowerment, preservation and development of customs and traditional institutions are stipulated in District Regulations.

(2) Regency Regulations referred to in paragraph (1) contain material including:

a. empowerment, preservation and development mechanisms;

b. the position, duties and functions of traditional institutions;

c. the rights, authority and obligations of Adat institutions including the authority in settling customary dispute disputes;

d. organization structure;

e. its relationship with government organizations, both village and district governments.

On November 30, 2001 the Government Regulation No. 76 of 2001 concerning General Guidelines for Regulations Regarding Villages (LN. 2001 No. 142) was enacted. With regard to the resolution of disputes and traditional institutions, its regulation are found in Articles 16, 39 and 40.

Article 16 determines that:

(1) The duties and responsibilities of the village head are to: 
a. lead the village administration.

b. foster rural community life.

c. foster the village economy

d.maintain peace and order in the village community.

e. represent their village inside and outside the Court and can appoint their legal counsel, reconcile community disputes in the village.

(3) to reconcile disputes as referred to in paragraph (1) letter (o) the Village Head can be assisted by the Village Customary Institution;

(4) All disputes have been reconciled by the Village Head are binding on the disputing parties.

Article 39 states that:

(1) The Regional Government must follow and respect the customs and the Law No. 39 of 1999 concerning Human Rights.

(2) The Regional Government may stipulate various policies in the effort to empower, preserve and develop customs and traditional institutions in the region.

In this connection, it can be added that the Law No. 39 of 1999 concerning Human Rights (LN. 1999 No. 165) is regulated in Article 6 which states:

(1) In the context of upholding human rights, differences and needs in indigenous and tribal peoples must be considered and protected by law, the community and the government.

(2) Cultural identity of indigenous and tribal peoples, including rights to customary land are protected. in harmony with the times.

Article 40 the Government Regulation No. 76 of 2001 confirms that:

(1) Further regulations regarding empowerment, preservation and development of customs and traditional institutions are stipulated in the Regional Regulations in District level.

(2) the Regional Regulations in District level referred to in paragraph (1) contain, inter alia:

a. empowerment, preservation and development mechanisms;

b. the position, duties and functions of traditional institutions;

c. the rights, authorities and obligations of adat institutions including the authority of:

a) organizational structure; and

b) relations with government organizations, both Village Governments and District Governments.

Customary Institution according to the above provisions is an institution established to assist the Village Head in resolving customary disputes. An Adat institution is not an Adat court, but merely an institution to help the village head resolve Adat disputes. The Law No. 21 of 2001 concerning Special Autonomy for the Province of Papua is an instrument of public policy. The Indonesian government aims to provide solutions to the crucial problems that occur in Papua. These problems include: 1) political conflict, focusing on the issue of demands for an independent Papua which is seen by the Indonesian government as a separatist movement. 2) social conflicts between citizens as a result of the absence of adequate solutions to the opening up of political conflicts that arose earlier, and 3) the underdevelopment of economic development of society, especially the people of Papua, compared to most other provinces in Indonesia.

Thus, it can be said that politically special autonomous contains the division of authority between the centre and the regions through a more adequate decentralization policy. Socially, it contains recognition and respect for the socio-cultural identity and basic rights of indigenous Papuans within the framework of Indonesian Diversity. The recognition and respect for socio-cultural identity and basic rights of the community can be seen in Article 18 B paragraph (1) of the 1945 Republic of Indonesia, which states that "The State recognizes and respects regional government units that are specific or special nature regulated by law".

Regarding to the implementation of customary court as stipulated in the Law Number 4 of 2004 concerning Judicial Power, Article 1 determines that "Judicial Power is the power of an independent state to administer justice to enforce law and justice based on Pancasila, for the sake of the implementation of the Republic of Indonesia Law". Article 2 then determines that "The exercise of judicial power as referred to in Article 1 shall be carried out by a Supreme Court and some courts under its jurisdiction, namely the general court, religious court, and military court including the state administrative court and the Constitutional Court". Article 13 paragraph (1) furthermore provides that all courts in the entire territory of the Republic of Indonesia are state courts and are determined by law.

The above article clearly state that the exercise of judicial power is carried out by the Supreme Court and all courts in all regions of Indonesia are state courts, but the Law No. 21 of 2001 in CHAPTER XIV concerning judicial authority. Article 50 paragraph (2) and Article 51 paragraph (1) up to paragraph (8) determine that:

Article 50:

(1) Judicial power in the Papua Province is exercised by the Judiciary in accordance with statutory regulations;

(2) Aside from judicial authority as referred to in paragraph (1), the existence of customary justice is recognized 
in the customary law community.

Article 51

(1) Customary judiciary is a peace court within the customary law community, which has the authority to examine and adjudicate customary disputes in criminal cases among the members of the indigenous peoples concerned.

(2) The adat court is arranged according to the provisions of the adat law of the adat law community concerned.

(3) The adat court examines and adjudicates customary civil disputes and criminal cases as referred to in paragraph (1) based on the adat law of the adat law community concerned.

(4) In the event that one of the parties to the dispute or the litigant object to the decision that has been taken by the customary court examining it as referred to in paragraph (3), the party in question has the right to request a court of first instance within the court of competent jurisdiction to examine and adjudicate the relevant dispute or case.

(5) The adat court has no authority to impose a sentence of imprisonment and confinement.

(6) The court's decision regarding criminal offense for which the case is not required to be re-examined as referred to in paragraph (4), shall be the final decision and shall have permanent legal force.

(7) To free a criminal offender from a criminal charge according to the provisions of the applicable criminal law, a statement of approval is required to be carried out from the head of the district court in his territory, which is obtained through the head of the state prosecutor's office concerned with the place of the criminal event as referred to in paragraph (3).

(8) In the event that the request for statement of approval to be carried out for the decision of the customary court as referred to in paragraph (7) is rejected by the District Court, the decision of the customary court as referred to in paragraph (6) shall be taken into consideration in the District Court's legal judgment in deciding the case concerned.

The meanings of Article 50 and Article 51 paragraph (1) to paragraph (8) of the Law No. 21 of 2001 concerning Special Autonomy for the Province of Papua regulates the existence of a Customary Judicial Body to resolve civil and customary criminal cases. The point is that the Customary Courts resolve cases where the legal ruling is "peace" between the parties, but if the justice seekers want the legal ruling to "win and lose", then the place is in the District Court and the next level.

The implementation of the customary court based on the Special Autonomy of Papua Province, if it is necessary to get further serious review of its existence so that it does not clash with higher law. In addition, if it is explored in more depth Article 51 Paragraph (1) states that adat court is a peace court within the legal community, which has the authority to examine and adjudicate adat disputes and criminal cases among the members of the indigenous peoples concerned. Furthermore, paragraph (3) states that the adat court shall examine and adjudicate adat civil disputes and criminal cases as referred to in paragraph (1) based on the adat law of the adat law community concerned.

The provisions referred to in these two paragraphs and their explanations do not clearly state what civil disputes and criminal cases should be under the authority of the adat court as a peace court in the customary community. However, if examined further, customary law does not recognize the division of civil law into criminal law, so it is natural that the formulation of the article is not explicitly stated in disputes or civil cases or the field of criminal law.

\section{Conclusion}

The pattern of resolving customary violations through handling by and with local adat cannot be released with the pattern of the Waropen tribe as a legal alliance and is based on a thought that the punishment is based on the Criminal Code (WvS) which has been happening in practice, do not meet the demands of the sense of justice of the people who are still familiar with and apply criminal customary law. The loss caused by adat offense does not only involve material loss, but also immaterial loss. This clearly shows that customary criminal law is based on a philosophy of harmony and 'communal morality'. He strongly rooted the community's belief, that in the case of adat offense that resulted in immaterial losses, it had implications for concrete actions in the form of recovery efforts in the form of organizing certain rituals. In the view of the Waropen tribe, formal juridical settlement of adat cases through the 'criminal justice process' mechanism has not yet resolved the problem completely. However, in the arena of law enforcement the role and contribution of customary law cannot be denied that law enforcement is the alignment of values with human behavior by realizing ideas or values into the form of 'in concreto' law requiring judges as law enforcers and justice to explore, follow and understand the legal values that live in society. This fact shows that customary law is an important factor in law enforcement because the goal is the realization of a sense of justice. The incompleteness of codified law further strengthens the position of adat law in the resolution of adat cases. 


\section{Bibliography}

C.T. Onois (ed.), 1975, The Shorter Oxford English Dictionary, vol. 1, third edition, Clarendon Press, Oxford. Edward Goldsmith, 1998, The Way: An Ecological World-View, the University of Georgia Press, Athens, GA. MB Hooker, 1978, Adat Law In Modern Indonesia, Oxford University Press, Kuala Lumpur.

Neder and Todd, 1978, The Disputing Process, Colombia Press, New York.

Ratno Lukito, 2013, Indonesia Law Tradition, IMR Press, Yogyakarta. Soetoprawiro Koemiatmanto, 1994, Government and Indonesian Judiciary, Its Origin and Development, Citra Adtiya Bakti, Bandung.

Sudikno Mertokusumo, 1984, The History of Justice and Legislation in Indonesia Since 1942 and What Its Benefits Are for Us Indonesians, Liberty, Yogyakarta.

Tresna, 1978, Indonesian Judiciary From Century to Century, Pradnya Paramita, Jakarta.

Z. Asikin Kusumah Atmadja, 1980, "Politics of National Law" in Abdul H. Nusantara and Nasroen Yasabari (ed.) Some Thought of Legal Development in Indonesia, Alumni, Bandung. 